
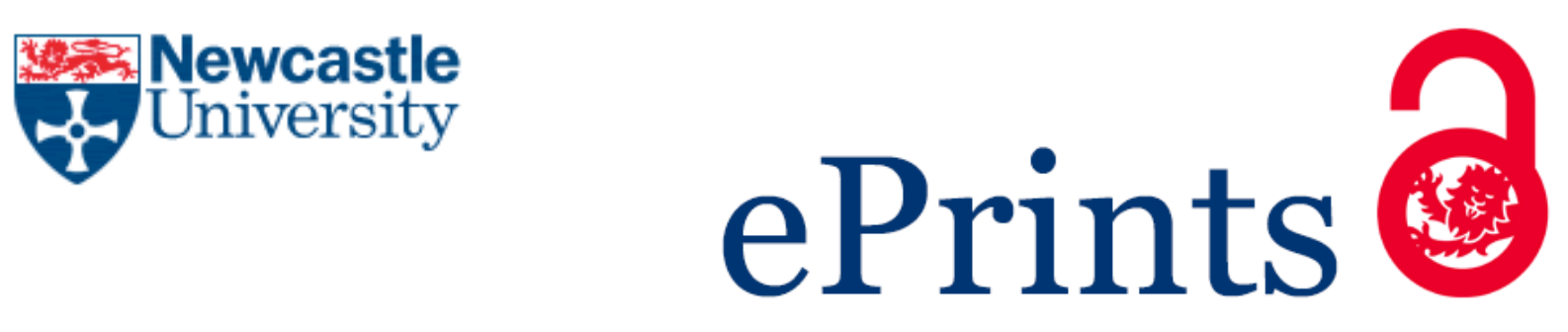

Saunders D.

Challenge, Decline and Revival: The Fortunes of Pacifism in Nineteenth- and Early Twentieth-Century Newcastle. Northern History 2017, 54(2)

\title{
Copyright:
}

This is an Accepted Manuscript of an article published by Taylor \& Francis in Northern History on $11^{\text {th }}$ April 2017, available online: http://www.tandfonline.com/10.1080/0078172X.2017.1309755.

DOI link to article:

http://doi.org/10.1080/0078172X.2017.1309755

Date deposited:

$03 / 04 / 2017$

Embargo release date:

11 April 2019

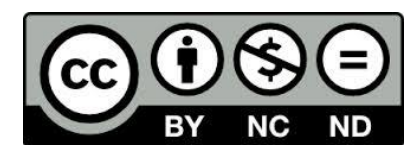

This work is licensed under a

Creative Commons Attribution-NonCommercial-NoDerivatives 4.0 International licence 
Challenge, Decline and Revival: The Fortunes of Pacifism in Nineteenth- and Early Twentieth-Century Newcastle

\section{DAVID SAUNDERS}

\section{Newcastle University}

When Britain's imperialism was reaching its peak, when the country sometimes used force to impose its goods on foreign markets, when industrialists profited from manufacturing the sinews of war, when a determined approach to foreign affairs could win elections, and when some people even thought it permissible to impose freedom on other societies by force, persuading British people to be pacifists was difficult. It appears to have been particularly difficult in north-east England, where the Coldstream Guards, the Northumberland Fusiliers and Admiral Collingwood of Trafalgar illustrated the local population's combative inclinations and all the region's major products - coal, ships, Stephenson engines, the Armstrong gun, the steam turbine - had actual or potential military applications. To judge by the applause that an Anglican priest received when he spoke in praise of the Armstrong gun at Elswick (just to the west of Newcastle) in 1860, he was not alone among local people in his view that 'Power to prosecute a war vigorously was the best way to preserve peace'. ${ }^{1}$

Yet the case for non-military approac hes to the conduct of international relations did not go by default in early and mid-nineteenth-century Newcastle. The Armstrong gun may have impressed a local Anglican priest, but local nonconformists - especially Quakers, but also Baptists, Primitive Methodists, Congregationalists, and Scotch Presbyterians -

\footnotetext{
${ }^{1}$ Newcastle Guardian (NG), 18 Aug. 1860, p. 3.
} 
maintained a local branch of the national Peace Society between October 1817 and April $1869 .^{2}$ By the standards of peace activists, furthermore, members of the Newcastle branch tended to be radicals, what scholars would now call 'pacifists' rather than 'pacificists'; in 1842, indeed, they disaffiliated from the Peace Society in London on the grounds of its moderation, returning to the fold only eight years later, when London had become more energetic. ${ }^{3}$ Their multifarious activities - distribution of tracts, organization of essay competitions, inviting speakers from elsewhere, reaching out to young people, holding their Annual General Meetings in public - confirm Peter Brock's assertion that, in the early days of the Peace Society, 'the main burden of work was carried by the auxiliary societies'; they make Newcastle a significant exception to Eric W. Sager's view that 'The Peace Society ... acquired most of its early support in the south of England' ${ }^{4}$

Prior to 1848 , however, advocates of peace in Britain were not often tested, mainly because the nation was not often at war. Although the Newcastle branch of the Peace Society organized a protest meeting when Britain fought in China, Afghanistan, and the Levant in $1839-40,{ }^{5}$ its members did not usually feel the need to subject their views to the approval or dispproval of the wider public. Life began to be more challenging for them in the wake of the European revolutions of 1848 , when Britain had to respond to the possibility of changes in the balance of power.

\footnotetext{
${ }^{2}$ For the date of the branch's foundation, see 'Correspondence on the Peace Society', Northumberland and Newcastle Monthly Magazine 1 (1818), 89; for its closure in 1869, see below. For the greater involvement of nonconformists than of Anglicans in the British peace movement of the nineteenth century, see, for example, Peter Brock, Pacifism in Europe to 1914 (Princeton, 1972), p. 378; N. W. Summerton, 'Dissenting Attitudes to Foreign Relations, Peace and War, 1840-1890', Journal of Ecclesiastical History 28 (1977), esp. 152; and Michael R. Watts, The Dissenters (3 vols, Oxford, 1978-2015), ii. 569-74.

${ }^{3}$ For the terms 'pacifist' and 'pacificist', see Martin Ceadel, The Origins of War Prevention: The British Peace Movement and International Relations, 1730-1854 (Oxford, 1996), pp. 35-57. For the dealings of the Newcastle branch of the Peace Society with the national body in 1842 and 1850, see Ceadel, Origins, pp. 310-11, 441. The radicalism of the Newcastle branch is clear in a report it submitted to the parent body in 1832: Herald of Peace, $2^{\text {nd }}$ ser., 8 (1831-2), 280-7.

${ }^{4}$ Brock, Pacifism, p. 379; Eric W. Sager, 'The Social Origins of Victorian Pacifism', Victorian Studies 23 (1980), 214.

${ }^{5}$ Newcastle Journal (NJ), 26 Dec. 1840, p. 3.
} 
After the Second Republic and then the Second Empire supplanted the Orleanist monarchy in France, Britain felt it had to prepare for the possibility of threats from the other side of the English Channel. How it was to do so proved contentious. Lord John Russell's ministry fell at the beginning of 1852 after proposing a means of raising additional military forces. Lord Derby's incoming administration put forward an acceptable way of raising them. Opposed to both methods, Newcastle pacifists now began to discover how unpopular resistance to military recruitment could make them. A letter in a local newspaper asserted that 'In the present state of human affairs, it is perfectly absurd to maintain the views of the Peace Society men'. ${ }^{6}$ Later, when Derby's proposals had become law, a second letter deplored the display of a placard attacking the new legislation 'in the shop of a Teetotal, Peace SocietyVegetarian-Phrenological Bookseller'. According to the second correspondent, opponents of the new law 'take the anti-national side, and justify all aggressions on this country, French and American, however flagrant, stigmatizing our brave officers as murderers, whether they put down pirates in Borneo, or rebels in Ireland,...'?

Meanwhile, at the far end of the European mainland, Russia had occupied the Danubian Principalities of the Ottoman Empire in 1848 and invaded Hungary to assist in the suppression of Lajos Kossuth. The tsar's forward moves touched a nerve in Newcastle, for Russophobia had been a feature of local politics since at least 1838 , when leading merchants in the town had been captivated by the violently pro-Turkish and anti-Russian views of the quixotic ex-diplomat David Urquhart. ${ }^{8}$ In the wake of Russian aggression, Newcastle began baying for action. At the end of 1849, a public meeting in the centre of the town 'in Aid of

\footnotetext{
${ }^{6} \mathrm{NJ}, 24$ Apr. 1852, p. 7.

${ }^{7}$ NJ, 21 Aug. 1852, p. 7.

${ }^{8}$ NJ, 17 Nov. 1838 , p. 3, and 24 Nov. 1838, p. 3. Studies of Urquhart's career which relate particularly to the subject-matter of the present paper include Olive Anderson, A Liberal State at War: English Politics and Economics During the Crimean War (1967), pp. 139-52, and Richard Shannon, 'David Urquhart and the Foreign Affairs Committees', in Patricia Hollis (ed.), Pressure from Without in Early Victorian England (1974), pp. 239-61.

${ }^{8}$ Herald of Peace, $3^{\text {rd }}$ ser., 2 (1840-1), 278-81, 313.
} 
the Hungarian and Other Refugees' contemplated the possibility that the tsar might invade the Ottoman Empire to compel the Turks to return the fugitive Kossuth to Austria. The ironmaster George Crawshay, a leading local Urquhartite, spoke up for the Hungarians. In a deliberate attack on pacifists, he claimed that although he was 'averse to war', 'he could not go to the length of the Peace Society'. ${ }^{9}$ The cheers to which his address resounded made clear that the local community cared less about pacifism than they did about using Britain's military might to support continental liberation movements.

The invidious position in which Newcastle's pacifists now found themselves deteriorated further in the crisis which led to the Crimean War. Less than three weeks after Russia destroyed the Turkish fleet at Sinope on the southern coast of the Black Sea in November 1853, people in Newcastle expressed their enthusiasm for military action in support of the Turks. A strongly anti-Russian public meeting, 'crowded to excess', heard Sir John Fife attacking 'the arguments of the Peace Society' and urging Parliament to take note of the 'imminent peril to the liberty and civilization of Europe' which resulted from the Russian threat to Turkey. ${ }^{10}$ Crawshay said that 'He might have called upon Government at once to declare war with Russia, instead of applying to Parliament'. The young Joseph Cowen, a brick manufacturer who was to be one of the most important figures in Newcastle politics for much of the next thirty years, 'denounced the present coalition Government as one based upon the want of principle, and severely condemned the Russian tendencies of Lord Aberdeen'. ${ }^{11}$ By this time Urquhartism was at its height in Newcastle. Although the pacifist Robert Haggie, a rope-maker, tried to persuade people to think seriously about the

\footnotetext{
${ }^{9}$ Newcastle Courant (NC), 23 Nov. 1849, p. 3. The best study of Crawshay is Joan Allen's entry on him in the online edition of the Oxford Dictionary of National Biography (Oxford, 2004 and subsequently, hereafter ODNB), http://www.oxforddnb.com/view/article/46851?docPos=1 (last accessed 25 January 2017). ${ }^{10}$ NJ, 17 Dec. 1853, p. 6 (from which the subsequent quotations in this paragraph are also taken). On Fife, a former Mayor of Newcastle, see W. L. Burn, 'Newcastle upon Tyne in the Early Nineteenth Century', Archaeologia Aeliana 34 (1956), 6, 10.

${ }^{11}$ On Cowen, see ODNB, http://www.oxforddnb.com/view/article/6494?docPos=1 (last accessed 25 January 2017).
} 
financial and human costs of war, 'after attempting for some time to proceed, ... [he] was obliged to resume his seat'.

Thus, in the Crimean War, Newcastle's mix of commercial self-interest, delusional Turcophilia, romantic attachment to European liberation movements and visceral anti-tsarism overwhelmed local peace advocates. Although they went on trying to convince local people of the error of their ways, they did not make many converts. When they brought Henry Richard, the energetic secretary of the national Peace Society, to lecture in the town, the room in which he spoke was 'scarcely half-filled' and the chairman had to admit 'that ... the peace cause was not popular'. Although George Dodds claimed on this occasion that 'those who took a leading part in the war meeting ... had not dared to come', they probably did not think it necessary to do so. Dodds's view that 'it was impossible to sustain the independence of Turkey' because it was 'a decaying power', and that, if Britain went to war on behalf of Turkey, 'we should be fighting to keep down our fellow-Christians', had little purchase in Newcastle at a time when Urquhartism so coloured local attitudes. ${ }^{12}$

The town's militarism at the time of the Crimean War came to be inspired not only by Urquhart's pro-Turkish Russophobia but also by the idea of liberating the minority peoples of the Russian Empire. A large public meeting at the end of August 1854 heard Crawshay argue that the way to defeat Russia was by encouraging her Finnish and Polish subjects (not to mention the Circassians of whom Urquhart was so enamoured). ${ }^{13}$ Charles Attwood, another iron-master, veteran of the campaign in Newcastle for the passage of the Great Reform Bill of 1832 (and brother of the more famous Thomas Attwood of Birmingham), claimed that the British government was actually in league with Russia. The British Prime Minister and the Russian Tsar, he said, had secretly agreed to partition the Ottoman Empire in 1844.

\footnotetext{
${ }^{12}$ NG, 11 Feb. 1854, p. 4. A flax-dresser by training, George Dodds (1810-88) had abandoned the strong-arm tactics of early trade unionism for Primitive Methodism and temperance and eventually became Mayor of Tynemouth (Shields Daily Gazette [SDG], 5 Dec. 1888, p. 3).

${ }^{13} \mathrm{NG}, 2$ Sep. 1854 , p. 3.
} 
Consequently, British forces were only 'nominally' at war. They were 'reaping no laurels, fighting no battles, assisting no ally, ... gaining no victory, ... and expiring, ... like candles in a fog and on a barren land'. Other speakers spoke only a little less forcefully. ${ }^{14}$ At the end of October 1854 Urquhart himself came to Newcastle to thank the town for its longstanding support. ${ }^{15}$ In November, Cowen and others (by this time calling themselves the 'Newcastle Foreign Affairs Committee'), continued the attempt to persuade people to think of Polish liberation rather than the defence of the Ottoman Empire as the principal purpose of the war. ${ }^{16}$ By March 1855, Cowen was very much in the vanguard of this approach to the question of Britain's war aims. ${ }^{17}$ Although local critics varied in their understanding of what exactly was wrong with Britain's war effort, they all thought that it had to be conducted with greater vigour.

In these circumstances, pacifists had little chance of impressing the local community. To judge by the address of the former MP George Thompson to an anti-war meeting in Newcastle in April 1855, they were more beleaguered than ever. When Henry Richard had spoken in the town on behalf of the Peace Society in February 1854, the local war-mongers had ignored him. Now, Cowen went on to the offensive. A local newspaper reported that: a hand-bill had been largely circulated during the day, appealing to working-men to attend the Lecture-room at seven o'clock in the evening and 'let George Thompson and the peacemongers understand that they would not turn renegade to their oftdeclared principles'. ${ }^{18}$

At the meeting itself, Cowen proposed a motion to the effect that 'the war was necessary; that at the same time they [the audience] deprecated its management; and that it was essential to

\footnotetext{
${ }^{14}$ NG, 2 Sep. 1854, p. 3; NJ, 2 Sep. 1854, p. 7. On Attwood, see ODNB, http://www.oxforddnb.com/view/article/52577 (last accessed 25 January 2017).

${ }^{15} \mathrm{NJ}, 28$ Oct. 1854, p. 7.

${ }^{16} \mathrm{NC}, 1$ Dec. 1854, p. 2.

${ }^{17}$ NG, 31 Mar. 1855 , p. 8.

${ }^{18}$ NG, 14 Apr. 1855, p. 8.
} 
the peace of Europe that Poland should be established as a barrier to Russia' ${ }^{19}$ Its passage showed that Newcastle's militants were in a majority in 1855 even at meetings convened by their opponents. More than fifty years later, when recalling that he had been 'too young to have any weight' at the time of the Crimean War, Newcastle's principal nineteenth-century peace activist, Robert Spence Watson, was to remember that local Quakers had 'held a meeting against it' at which they had been 'hopelessly beaten, and chiefly by Joe Cowen'. ${ }^{20}$

The prospects for peace-lovers continued to diminish in Newcastle in the decade and a half between the end of the Crimean War and the dissolution of the local branch of the Peace Society in 1869. Not only were these the years of the invention of the Armstrong gun (and the dredging of the River Tyne and the coming of iron ships, both of which improved the town's connections with the wider world), but local Russophobes also interpreted international developments of the year 1859 as fresh evidence of Russian machinations and vigorously opposed the tsar at the time of the Polish insurrection of January $1863 .^{21}$ In the face of continuing challenges to their views, Newcastle pacifists lost heart. At the Annual General Meeting of the local branch of the Peace Society in 1860, George Thompson (the man who had lost the vote when Cowen intervened against him at the pacifists' anti-war meeting of 1855) lamented the fact that "the education of the people of this country should almost universally be in favour of war, and that so much of our money should be wasted - worse than wasted - in matters connected with warlike pursuits'. Thompson dubbed the profession of soldier to be 'the lowest, the most useless, the most pernicious' of all, and found it distressing to witness 'the strange - almost universal and wilful - indifference on the part of the clergy of our land to such matters'. ${ }^{22}$ At the beginning of the following year, the most

\footnotetext{
${ }^{19}$ NJ, 14 Apr. 1855 , p. 5.

${ }^{20}$ Robert Spence Watson, Reminiscences 1837-1911 (York, 1969), p. 6.

${ }^{21}$ G. Crawshay, The European Complication Explained (Newcastle-on-Tyne, n.d. [but dated 20 April 1859 on p. 9]); John F. Kutolowski, The West and Poland: Essays on Governmental and Public Responses to the Polish National Movement, 1861-1864 (Boulder, CO, 2000), p. 230.

${ }^{22}$ NG, 5 May 1860 , p. 3.
} 
conservative of the Newcastle newspapers reiterated the perennial charge of militarists that pacifism was tantamount to treason. ${ }^{23}$ Commenting on the 1861 annual meeting of the Newcastle branch of the Peace Society, it held that it was 'difficult to say whether the Utopian ideas which he [the chairman] put forth' would ever amount to 'anything more tangible than the day-dream of a visionary'. ${ }^{24}$ In 1863, a visiting Anglican clergyman echoed the vicar who had sung the praises of the Armstrong gun a few years earlier when he argued, in a public lecture at Newcastle, that in view of the forthcoming end of the world Britain had to be ready for anything. Pacifism, he felt, laid the country open to attack; 'The best peace society was England prepared and perfectly armed' ${ }^{25}$

In April 1865, the Newcastle branch of the Peace Society tried to increase support for its principles by bringing the President and Secretary of the national body to the town for an afternoon 'Peace Conference' and an evening public gathering. The evening occasion opened bullishly, when a speaker proposed that 'They should ask every candidate for Parliament whether he was for peace or war'. Henry Richard, the national Secretary, then congratulated Britain on its non-intervention in the recent war between Prussia and Denmark and went on to propose international arbitration and arms reduction. Speaking to his motion, he confronted what, so far as the local branch of the Peace Society was concerned, was the question of the hour: whether there was any need for a peace society. 'Was it not presumptuous and impertinent in a small body of men organising themselves for that purpose, whilst all men were equally desirous for peace?' Predictably, Richard answer his question in the negative, resting his case on the enormous periods of time that nations spent fighting each other, their enormous expenditure on warfare, and the enormous resulting loss of life. In his view, Britain was not abiding by the Christianity it avowed. ${ }^{26}$

\footnotetext{
${ }^{23}$ Newcastle Daily Journal (NDJ), 21 Jan. 1861, p. 3.

${ }^{24}$ NDJ, 22 Oct. 1861, p. 2.

${ }^{25}$ Newcastle Chronicle, 26 Sep. 1863, p. 2.

${ }^{26}$ NDJ, 14 Apr. 1865, p. 2.
} 
Unfortunately, even the substantial contributions of Henry Richard and the President of the national body were insufficient to rescue the Newcastle branch of the Peace Society from its spiral of decline. In 1867, the local chairman of the annual general meeting freely admitted that 'the society was one that certainly could not be said to be very popular' ${ }^{27}$ Two years after that, the branch closed itself down. George Charlton, the Gateshead Primitive Methodist who chaired the final meeting, was bitter. He 'regretted that so very few in this Christian country acted upon the principles of peace as inculcated in the Gospel'; 'Many', he said, 'were with the society in denouncing war in general, but when it came to any particular war, which they themselves thought right, they were as enthusiastic for it as any general in the army: and even ministers of the Gospel could speak enthusiastically about the success of our arms'. ${ }^{28}$ A local newspaper, on the other hand, expressed what was almost certainly the majority view of local people when it commented sardonically that 'The Millennium must be near at hand, for the Newcastle Peace Society has been quietly gathered to its fathers ... the dissolution of the society must, unquestionably, be regarded as one of the most hopeful signs of the times! 29

Thus it appears that the Newcastle branch of the Peace Society had been constrained by Newcastle's devotion to commerce and industry and the town's enthusiasm for Britain's overseas military engagements. Just as its foundation in 1817 seems to contradict Eric W. Sager's claim that most supporters of the Peace Society in its early days were southerners, so its closure in 1869 seems to undermine Sager's further claim that 'a very rapid shift to the north' occurred in support for the Peace Society in the late $1860 \mathrm{~s}^{30}$

\footnotetext{
${ }^{27}$ NDJ, 23 Oct. 1867 , p. 3.

${ }^{28}$ NDJ, 14 Apr. 1869, p. 3. A butcher by profession, George Charlton (1810-85) went on to be Mayor of Gateshead in 1874-5 (SDG, 16 Sep. 1885, p. 3).

${ }^{29} \mathrm{NC}, 16$ Apr. 1869 , p. 8.

${ }^{30}$ Sager, 'Social Origins', 215.
} 
Ironically, however, Sager's second claim may in fact be justified in the case of Newcastle, for, eighteen months after the closure of the local branch of the Peace Society, the cause to which it had been devoted began to gain ground in the town. At the point of closure, members of the local branch had been invited to transfer their membership to the national body. Some of them remained committed to the cause of peace. At least one of them became much more strongly committed.

In 1870, the Franco-Prussian War gave Newcastle pacifists a chance to promote their cause by virtue of the fact that it exposed a contradiction in the political philosophy of Joseph Cowen. Because, at home, Cowen opposed the idea of standing armies, he took succour from German success in the Franco-Prussian War, which, in his opinion, demonstrated the inferiority of standing armies to the armed forces of countries which trained all their citizens in warfare but summoned them to the colours only from time to time. At a public meeting in Newcastle in late September 1870 (just after the capture of Napoleon III at the Battle of Sedan), he argued that the war on the other side of the Channel was validating his approach to military matters. 'If the issue of the war was such that it led to the abolition of standing armies in France,' he said, '...the blood ... would not have been shed in vain'. ${ }^{31}$

This opinion led Cowen into choppy waters., for T. Harwood Pattison, Baptist minister of Rye Hill Chapel in the west end of Newcastle, took up the implications of his speech for the pacifist cause of disarmament. 'Heartily as he coincided with the remarks made by $\mathrm{Mr}$ Cowen, he thought he should only be doing what was right when he stated that he appeared there as an advocate of peace principles. He was almost, if not altogether, in favour of peace at any price, for he believed that national dishonour was likelier to follow in the train of war than in the train of peace'. France had now offered to 'lay down her arms at once' if Prussia

${ }^{31}$ NDJ, 7 Sep. 1870, p. 2. 
did not annex any territory. This commitment to non-violence, Harwood Pattison implied, was even more important than the establishment of the new French republic. ${ }^{32}$

Other local peace activists now saw their chance. David Richardson, a Rye Hill Quaker, wrote to Pattison to suggest a second public meeting on the subject of standing armies. Cowen had indicated his hostility to them. Was not now the time to dwell on the possibility of their abolition? The Social Science Association was about to hold its annual congress in Newcastle. Many highly educated people would be coming to the town. The committee of the congress might be able to facilitate use of the Town Hall as a venue. ${ }^{33} \mathrm{~A}$ second public meeting duly took place in the Town Hall just under two weeks later. Although Cowen took the chair, the 'platform party' included not only Richardson and Harwood Pattison but also Henry Richard, the Secretary of the Peace Society (whose speech in Newcastle during the Crimean War in 1855 Cowen had taken steps to undermine) and George Charlton (who had spoken bitterly at the closure of the Newcastle auxiliary of the Peace Society the previous year). In this company, Cowen was a fish out of water. Although, in a long opening speech, he tried to distance himself from the Peace Society by explaining why, despite his opposition to standing armies, he was not opposed to the use of force in all circumstances (he would allow it, for example, 'when a military usurper destroyed the liberties of the country'), he then had to listen to Henry Richard's exposition of the case for pacifism. Richard could have been forgiven for feeling pleased to be able to speak in Newcastle without being interrupted. He pointed out that, in view of the Franco-Prussian War, 'it would have been well for the world if it had paid more heed than it had done to the principles which the Peace Society had

\footnotetext{
${ }^{32}$ NDJ, 7 Sep. 1870, p. 2. On Harwood Pattison (1838-1904) see Clyde Binfield, 'Nonconformist Architecture: A Representative Focus', in Robert Pope (ed.), $T$ \& $T$ Clark Companion to Nonconformity (2013), pp. $272-4$. ${ }^{33}$ David Richardson to T. Harwood Pattison, 11 September 1870, Cowen Collection on microfilm, Local Studies, Newcastle upon Tyne Central Library, reel 6, unnumbered document between B97 and B98. On Richardson, see Ruth Sansbury, Beyond the Blew Stone: 300 years of Quakers in Newcastle (Newcastle upon Tyne, 1998), esp. p. 221. On the Social Science Association, see Lawrence Goldman, Science, reform, and politics in Victorian Britain: The Social Science Association, 1857-1886 (Cambridge, 2002).
} 
promulgated, and the measures which it had recommended in order to regulate the intercourse of nations.' Going on to ask 'What did the Peace Society say?', he answered the question as follows:

It said this: there were better means, wiser means, means more rational, more humane, more Christian for settling differences between nations than by the system of wholesale and mutual murder - for disguise it as they might it was nothing less than murder in mass.

In Richard's opinion, the adage 'If you wish for peace, you must prepare for war', was equivalent to saying, 'If you wish for sobriety, prepare for drunkenness'. Maintaining standing armies, he thought, was like filling your house with gunpowder and then letting children play there (diplomats and princes being the children). On a tour of Germanic Europe and France in 1869 to persuade politicians to put forward motions for arms reduction, he had found that many of them were willing to do so. They in turn had discovered that arms reduction was a popular cause; 'this feeling, he was convinced, prevails throughout Europe'. ${ }^{34}$ Concluding its report on the meeting, a local newspaper called it 'one of the most successful ... ever held by the Peace Society’. ${ }^{35}$ Although, strictly speaking, it had not been called by the Peace Society, for once a presentation of the pacifist case had prevailed in Newcastle.

A month later, furthermore, the man who was to be nineteenth-century Newcastle's most significant pacifist, Robert Spence Watson, set off for Metz in northern France on a Quaker mission to help victims of the fighting. No more than a teenager when local pacifists were being bested at the time of the Crimean War, Spence Watson was now approaching the peak of his powers. Although he was to be prominent in both local and national Liberal

\footnotetext{
${ }^{34}$ NDJ, 26 Sep. 1870 , p. 6.

${ }^{35}$ Northern Echo, 26 Sep. 1870, p. 4.
} 
politics (serving as Cowen's election agent in the 1870s and 1880s, and as President of the National Liberal Federation from 1890 to $1902^{36}$ ), his principal allegiance was always to the Society of Friends. After education at the Friends' School, York (now Bootham School), and subsequently, for a time, at University College, London, he had returned to Newcastle to work in his father's legal practice. Although, as an adult, he went on travelling, mountaineering, and running the affairs of Newcastle's Literary and Philosophical Society, commitment to Quaker causes remained his defining characteristic. In the mid-1870s, Disraeli asked Cowen whether Spence Watson meant it when he said he would prosecute the Prime Minister if a British 'Fugitive Slave Circular' took effect. Cowen replied: '... he is a Quaker, and, if he has said so, you may depend upon it he not only means it but, if the occasion arises he will do it whatever the cost may be' ${ }^{37}$ Of his prominence at the time of his Presidency of the National Liberal Federation, an obituarist wrote that 'Probably no man outside Parliament exerted a wider political influence than he did in those days' ${ }^{38}$ The reason he did not enter Parliament was that his understanding of Quaker principles required him not to do so. A second obituarist wrote that 'he took more pains to keep out of Parliament than many men expend in trying to get there'. ${ }^{39}$ A dedicated exponent of the practice of speaking truth to power (long before the invention of the expression), he told Rosebery to his face that he was not a suitable person to be Prime Minister because he had been given everything on a plate and had never contested an election. A lifelong advocate of the abolition of the House of Lords, he refused a knighthood after the Liberal landslide of 1906 and accepted

\footnotetext{
${ }^{36}$ On Spence Watson in local politics, see E. I. Waitt, 'John Morley, Joseph Cowen and Robert Spence Watson: Liberal Divisions in Newcastle Politics 1873-1895', unpublished PhD dissertation, Manchester University, 1972. For his 'commanding influence' in the context of the National Liberal Federation, see Augustine Birrell, 'Prefatory Note', in Robert Spence Watson, The National Liberal Federation: from its commencement to the general election of 1906 (1907), p. $\mathrm{x}$.

${ }^{37}$ Spence Watson, Reminiscences, p. 61. On Britain's slave circulars of the mid-1870s, see William Mulligan, 'The Fugitive Slave Circulars, 1875-76', Journal of Imperial and Commonwealth History 37 (2009), 183-205.

${ }^{38}$ The Times, 3 Mar. 1911, p. 4.

${ }^{39}$ Yorkshire Post, 3 Mar. 1911, p. 7. For one of the occasions on which Spence Watson refused to stand for Parliament, see 'The Representation of Newcastle,' Newcastle Daily Chronicle (NDC), 17 August 1893, p. 4.
} 
appointment to the Privy Council in 1907 only on condition that he would not have to wear a sword at the swearing-in. The obituarist of the American Peace Society called him 'a Liberal of the most fundamental type'. ${ }^{40}$

Spence Watson's refusal to wear a sword reflected his pacifism. In his case, the refusal was more than a matter of Quaker convention, for he had seen what war could do. Northern France in the wake of the German invasion of 1870 appalled him:

I wish I could tell you how I loathe this war. It is too horrible. The misery which it brings with it is altogether incredible. I begin now to dream of it all night, for it has become a terrible reality. Bad I always thought it, but I never dreamed that it could be so bad. ${ }^{41}$

A decade later, he put his objections to war on a theoretical footing. '[T]he whole teaching, the whole life, the whole spirit of Christ,' he wrote, 'were opposed to the practice of anything approaching to war. There is not one saying of His which can be tortured into a command to use violence towards those who oppose you'. To the potential objection that Jesus said, 'I came not to send peace but a sword', he replied that the phrase related to disagreements between family members rather than states, and that anyway the sword which Jesus was talking about was the sword of the spirit and the peace he was talking about was complacency ('the Peace which laps the blind soul in false security'). To the argument that Christians were free to do what they wanted on questions of peace and war because Jesus had sought to effect only 'a change of the individual man, not of the societies into which men have gathered together', he replied that 'Either it is unnecessary for a Christian nation to be composed of

\footnotetext{
${ }^{40}$ The Advocate of Peace 73, № 4 (April 1911), p. 78. The only biography of Spence Watson is Percy Corder, The Life of Robert Spence Watson (1914). Some of the details mentioned in this paragraph come from Spence Watson, Reminiscences, pp. 2, 6-8, 20, 24, 27, 29, 59-63, 108. Others are from the Spence Watson/Weiss Collection in Special Collections, Newcastle University Library (hereafter Spence Watson/Weiss Papers), in particular SW/1/3/4, H. Campbell-Bannerman to Spence Watson, 20 Jun. 1906 (offering a knighthood); SW/1/3/5, the same to the same, 10 Jun. 1907 (offering a Privy Councillorship); and SW/3/22, Spence Watson to his wife, 27 Jul. 1907 (reporting that he had told the Lord High Chamberlain he objected to the sword).

${ }^{41}$ Robert Spence Watson, The Villages around Metz (Newcastle upon Tyne, 1870), p. 31.
} 
Christian men, or it must be subject to Christ's laws'. Although he conceded that a person 'gives up a portion of his liberty in return for the protection which the State, the nation, affords', he believed that 'if the governing power of that nation commands him to obey a law which is contrary to the law of Christ, he is no longer bound to recognise the command' ${ }^{42}$

In accordance with these views, Spence Watson's approach to international affairs was always to stand up for victims whilst advocating enhanced use of all the pacifist's many alternatives to violence. In the Franco-Prussian War, he helped victims. In the next European imbroglio, the Balkan crisis of 1875-8, he advocated strict non-intervention. Although, in 1876, he expressed outrage at a public meeting in Newcastle when a member of the local 'Foreign Affairs Association' tried to explain away the Turks' 'Bulgarian atrocities', he did not believe, as some did at that juncture, that Britain should intervene against the Ottoman Empire on the behalf of the Bulgarians. ${ }^{43}$ When Cowen began giving the impression in 1877 that Britain might have to defend the Ottoman Empire against Russia, he was no more willing to advocate intervention on behalf of the Turks. On the contrary, he thought Cowen was: aiding in bringing about a state of public feeling which will end by driving England to the very thing which ... [earlier] ... you expressed your strong disapproval of - i.e. supporting Turkey by force of arms against Russia ... [C]an the effect of your words be other than that of ... re-arousing the feeling which plunged us into that Crimean War which I hoped and believed you looked back to with regret? ... [A]t the present time surely there is nothing to lead us to change our policy of watchful non-intervention. ${ }^{44}$

\footnotetext{
${ }^{42}$ Robert Spence Watson, The Anti-Christian Nature and Tendency of War (London, 1900, unaltered text of an 1881 lecture with an introduction written in November 1900), pp. 5, 10, 12-13. Spence Watson supported the Irish in their resistance to Britain's 'Irish Coercion Acts'; 'The honest man,' he wrote in this connection, 'must defy the unjust law, and take the consequence' (Robert Spence Watson, The Proper Limits of Obedience to the Law [Gateshead, 1887], p. 20).

${ }^{43}$ NDC, 7 Sep. 1876, p. 3.

${ }^{44}$ Spence Watson to Cowen, 30 Apr. 1877, Spence Watson/Weiss Papers, SW/1/3/54 (copy).
} 
When Spence Watson claimed towards the end of this letter that he was "not writing as a member of the Peace Society', his words did not ring true. By the last year of the crisis, his opposition to British intervention in the Balkans had become so objectionable to local Turcophiles that it put his life in danger:

In 1878 George Crawshay [the veteran Urquhartite] called a meeting in sympathy with Turkey for the Old Lecture Room ... Crawshay had about forty of his great labourers with him. He had had them over at the Turks Head and filled them with whisky, and those fellows were ready for anything. They would have murdered a man without the slightest hesitation and as soon as I got up by Hall [the chairman] they attacked the platform ... They beat me from head to foot as hard as ever they could, and, amongst others, old Gregson, who was a watchmaker in Collingwood Street, seized me and injured me very much indeed, and ultimately they beat me until I became unconscious ... They called out that they would drop me over the stairs, and they got me to the stairs and held me over, head downwards. If they had dropped me, the place below was full of rakes, and as it was about twenty-five feet down, I should never have escaped with life, but just at the critical moment my men succeeded in getting up and as they were in the majority there was a terrible fight for my body and ultimately they beat off the Crawshayites. ${ }^{45}$

This was the first of two occasions when Spence Watson risked his life for his pacifist views. The other resulted from his hostility to British behaviour in Africa. He had first taken exception to Britain's forward moves in Africa during the Anglo-Zulu war of 1879. Britain, he wrote at that time, had driven the Dutch from the Cape at the beginning of the century. Now, he said, 'The English people are engaged in a strange enterprise in South Africa. They

\footnotetext{
${ }^{45}$ Spence Watson, Reminiscences, p. 69. For other occasions on which George Crawshay displayed his Turcophilia in the Balkan crisis of 1875-8, see NDC, 8 Sep. 1876, p. 3, and NC, 12 Oct. 1877, p. 7.
} 
are deliberately and of malice aforethought compassing the subjugation and possible extermination of a gallant though savage people' ${ }^{46}$ The country's African policy was at odds with the part it had played in the abolition of slavery and suppression of the slave trade. 'England,' Spence Watson wrote, has in late years done much for native peoples. She has purged away from her thoroughly at last the gigantic crimes of the slave trade and of slavery ... She has avowed herself the protector and friend of the coloured race; she has shown her practical belief in the universal brotherhood of man. Is she not strong enough and brave enough to-day to acknowledge that she has been made to sin grievously, in these Dutch and Zulu matters, against her own faith and in spite of her truest convictions? Will she not show the nations of the world that, to her, honour is dearer than revenge; and that Justice and Mercy, Honesty and Truth, are more righteous and more powerful factors in the dealings of man with man than all the gigantic and infernal paraphernalia of thriceaccursed War? ${ }^{47}$

When Britain adopted a forward policy in Egypt and the Sudan in the 1880s, Spence Watson spoke out again, though this time more carefully because the behaviour he deplored was taking place under a Liberal government. Shortly after the death of General Gordon at Khartoum, he expressed the hope that Britain's military operations in Sudan would come to an end very soon. 'The principal question before the constituencies in 1880 ,' he said, 'was the "spirited Foreign Policy" of the Tory Government ... That policy was condemned by the deliberate verdict of the nation. It is little wonder that this should have been so, for it had been as disastrous and humiliating in reality as it had been flashy and pretentious in appearance. In three short years England had begun a reckless course of aggression, the evil

\footnotetext{
${ }^{46}$ Robert Spence Watson, The History of English Rule and Policy in South Africa (Newcastle upon Tyne, 1879), p. 1.

${ }^{47}$ Spence Watson, History of English Rule, p. 32.
} 
effects of which she may never quite shake off'. Since 1880, Liberal foreign policy had been reasonably satisfactory. Admittedly, Britain had experienced problems in Egypt, but 'we do not, therefore, feel at all inclined to exchange the Liberal frying-pan for the Tory fire'. Even the recent troubles arising out of the death of General Gordon did not require a change of policy, though Liberal policy vis-à-vis General Gordon ought to have been just to rescue him, 'not to increase British or Egyptian responsibilities in the Soudan'. Gladstone had been mistaken to tell Sir Garnet Wolseley to go on the offensive in the wake of Gordon's death. British forces ought merely to have been withdrawn, though not on the grounds that they were needed in Afghanistan (for two wrongs did not make a right), and not in order to let Sudan might fall into the hands of another power (for 'we have no conceivable right to give away that which does not belong to us'). ${ }^{48}$

After the Tories came to power in 1895 , Spence Watson returned to unequivocal condemnation of Britain's overseas adventures. In a speech of 1897 he claimed that 'there had been one war larger or smaller or something partaking of the nature of a war, at all events for every two months which the Tories had been in power'. The Jameson Raid in southern Africa had been 'a miserable and squalid thing'. Although, in his days as a Liberal, Joseph Chamberlain had described the British Empire as 'more than sufficient for the most exalted desire', 'Since that time we have added four million square miles to this empire and $\mathrm{Mr}$ Chamberlain [now a Unionist] was still crying out for more, more, more'. Expansion, Spence

\footnotetext{
${ }^{48}$ Robert Spence Watson, The Government and the Soudan (a speech of 17 April 1885 at a meeting of the Council of the National Liberal Federation, printed without publishing details, Spence Watson/Weiss Papers, SW/10/4, pp. 1, 5-8). For further indications of Spence Watson's opposition to British behaviour in Egypt and the Sudan, see Spence Watson/Weiss Papers, SW/1/16/8, Henry Richard to Spence Watson on behalf of the Peace Society, 5 Apr. 1884 ('You know ... how this miserable Egyptian business embarrasses us at this moment. I hardly know where to turn for assistance, there are so few who on this subject have kept their consciences clean ... [But] I can trust you both for loyalty to principle and for discretion in your advocacy of our cause'), and NC, 20 Feb. 1885, p. 2, and 27 Feb. 1885, p. 4.
} 
Watson said, was immoral; Britain had no right to subject native peoples to its rule; people who 'followed Mr Chamberlain ... threw the teaching of Christ to the wind' ${ }^{49}$

The Boer War brought these views to a head. When it was still in the offiing, Spence Watson hoped that it could be avoided:

Men are beginning to speak out [he wrote to his wife] and the fact that the majority are against war is beginning to make itself known. Yet things are most critical. The troops on the two sides are facing each other, and a very little mistake could send the whole fire ablaze. How terrible it would be. ... I keep comparing the present state of things with that existing at the time of the Crimean War when the whole nation went mad for war. I have never until now felt how much real progress had been made in the sacred cause of Peace. In spite of everything I can find encouragement at the bottom of the present $_{\text {crisis. }}{ }^{50}$

In October 1899, however, a pro-peace meeting in Newcastle descended into chaos. ${ }^{51}$

Although Spence Watson did not know it until afterwards, a man with a gun stood behind him to defend him. 'It would have been a miserable sort of thing,' he wrote later, 'if the [future] President of the Peace Society had been the cause of a man in favour of war being shot dead' ${ }^{52}$ This was the second occasion on which he risked his life for the sake of his pacifist views. In March 1900, when the South African peace activist Samuel Cronwright Schreiner came to stay with him to address a Gateshead 'Stop the War' meeting, the event had to be called off for fear of violence and warmongers smashed some of his windows. ${ }^{53}$ By November 1900, his earlier optimism had deserted him. '[N]o lessons could be stronger,' he

\footnotetext{
${ }^{49}$ Robert Spence Watson, On the Foreign and Colonial Policy of Lord Salisbury's Government (Alnwick, 1897), pp. 4, 10, 15.

${ }^{50}$ Spence Watson/Weiss Papers, SW/3/27, Spence Watson to his wife, n. d., but clearly before the outbreak of the war.

${ }^{51}$ NC, 14 Oct. 1899 , p. 8.

${ }^{52}$ Spence Watson, Reminiscences, pp. 102-3.

${ }^{53}$ SDG, 10 Mar. 1900, p. 3, and Spence Watson, Reminiscences, pp. 102-3.
} 
wrote, 'than those which the war in which our beloved country is now engaged teaches of the deadening effect of strife, of the deadly influence of militarism upon the body politic'; 'we are waging a war of revenge and extermination upon two free peoples'; 'If we are honest, we shall openly declare that, excepting in purely domestic and un-important matters, as a people we prefer Moloch to Christ'. 54 'It was simply horrible,' he wrote later, 'to see how from one end of the country to another the English people went mad'.55

By chance, the Boer War did something to clariify the puzzle of Spence Watson's dealings with Russian revolutionaries. As one of the founders, in 1890, of the not accidentally named 'Society of Friends of Russian Freedom' (SFRF), and its President until his death, he spent a good deal of the last part of his life assisting émigré Russians who, in many cases, were anything but peaceable. ${ }^{56}$ How could he number such people among his associates? He could not say, as Cowen did when trying to inject logic into his views on standing armies in 1870, that he would have fought for Cromwell in the seventeenth century and might have joined the Polish or Italian rebels of the mid-nineteenth century. Feliks Volkhovskii, editor of Free Russia (the SFRF's journal), probably expressed Spence Watson's views in a letter he sent him in January 1900. Professor Ritchie of St Andrews had just objected to a report in Free Russia about tsarist Russia's hostility to Britain's behaviour in South Africa. ${ }^{57}$

Volkhovskii correctly perceived that Ritchie wanted the SFRF 'to criticise and protest against the Russian views of the South African affairs; he is indignant of F.R.'s having kept to only stating the facts'. If, however, the SFRF went along with the Professor, Volkhovskii believed that the logical consequence would be that it should also urge 'Great Britain to invade Russia

\footnotetext{
${ }^{54}$ Spence Watson, The Anti-Christian Nature of War, pp. 1-2 (November 1900 introduction).

${ }^{55}$ Spence Watson, Reminiscences, p. 102. For a full account of attitudes towards the Boer War in Newcastle, see Guy Hinton, 'Newcastle and the Boer War: Regional Reactions to an Imperial War', Northern History 52 (2015), 272-94.

${ }^{56}$ The best account of the SFRF remains Barry Hollingsworth, 'The Society of Friends of Russian Freedom', Oxford Slavonic Papers, new series, 3 (1970), 45-64.

57 Anon, 'South African Items', Free Russia 11 (1900), № 1, p. 2.
} 
for the purpose of introducing constitutional government into her'. Both British and Russian members of the SFRF, Volkhovskii said, always protested against such an idea. All they wanted was ... to show active sympathy with the Russian aspirants to freedom by materially and morally supporting the victims of tyranny, by educating public opinion, and, if possible, by preventing the British government from taking any step which might be a support to the Russian official system. But they could never wish the British to go, arms in hand, to coerce Russia into a better political organisation..${ }^{58}$

This seems to have been how Spence Watson justified his dealings with Russian revolutionaries: people outside a given country could take exception to its political arrangements and employ non-violent means to ameliorate them, but they ought not to try and change them directly. To draw a line under Professor Ritchie's complaint, he sent Volkhovskii a non-confrontational piece about Russian attitudes to the Boer War for the next issue of Free Russia and explained to the editor that he did not want to 'do anything which may prove to be unnecessarily aggravating, ${ }^{59}$ At the time of the Russian revolution of 1905 , he went on to make his opposition to the use of violence against the tsarist regime explicit by pointing out to David Soskice (Volkhovskii's successor as editor of Free Russia) that 'I am President of the Peace Society and I cannot subscribe to buy ammunition and the like' ${ }^{60}$

It may be that Spence Watson was actually less interested in toppling the tsar than in deprecating the violence he employed against his subjects, for although, in general terms, he was a believer in change (he was a keen Home Ruler, for example, and described Gladstone's last substantial achievement, the Parish Councils Act of 1894, as 'the mightiest change in the

\footnotetext{
${ }^{58}$ Spence Watson/Weiss Papers, SW/1/19/3, Volkhovskii to Spence Watson, 4 Jan. 1900.

${ }^{59}$ Robert Spence Watson, 'South Africa and the Russians', Free Russia 11 (1900), № 2, pp. 13-4; Spence Watson to Volkhovskii, 10 Jan. 1900, Houghton Library, Harvard University, bMS Kilgour Russian 51 (362). ${ }^{60}$ Parliamentary Archives, London, STH/DS/1/WAT.7, Robert Spence Watson to David Soskice, 24 Jan. 1905.
} 
conditions of rural life that our country has known ${ }^{61}$ ), his hostility to the tsarist regime seems to have been inspired at least as much by the physical damage it did to the inhabitants of the Russian Empire as it was by the regime's unrepresentative nature. Perhaps rightly, The Times reported his foundation of the SFRF in 1890 under the heading 'Agitation Against Russian Atrocities' (rather than under something like 'Movement for Change in Russia'), ${ }^{62}$ and in and after the 1905 revolution he dwelt on the violence of events in Russia rather than the country's new constitution or the possibilities exemplified by the first two sessions of its new parliament. ${ }^{63}$

Weapons and their effects continued to appal Spence Watson in the last years of his life. Indeed, they may have appalled him more in the early twentieth century than they did when he witnessed the effects of the Franco-Prussian War, for he was particularly disappointed by two of the most significant new developments in the field of warfare: the failure of an international attempt at arms control and the arrival of the Dreadnought class of battleship. Ironically (in view of his Presidency of the Society of Friends of Russian Freedom), the first of these two developments originated in a call from the tsar. On 16/28 August 1898, Nicholas II appealed to the international community to arrange a meeting to discuss 'the most effective means of assuring for all peoples the blessings of real and lasting peace, and above all things for fixing a limit to the progressive development of present armaments'. ${ }^{64}$ An international peace conference ensued at The Hague in the middle of 1899. One of Spence Watson's Russian associates viewed the initiative sceptically. 'The tendency to gather grapes from thornbushes,' he wrote, 'is one of the most tenacious and widespread

\footnotetext{
${ }^{61}$ Robert Spence Watson, Home Rule for Ireland: Fear or Hope? (Gateshead, 1893); Robert Spence Watson, 'Preface', in Corrie Grant, The Parish Councillor's Handbook (1894), p. 3.

${ }^{62}$ The Times, 25 Feb. 1890, p. 3.

${ }^{63}$ Robert Spence Watson, 'A Letter upon the Caucasian Massacres’, Free Russia 16 (1905), № 11, pp. 110-11; Robert Spence Watson, 'Government by Brute Force', Free Russia, June 1907 (no volume or part number), pp. 1-3; Robert Spence Watson, letter to the Daily News of 16 Jun. 1909 protesting about Nicholas II's forthcoming visit to Cowes on the grounds that he had 'carried out the massacre of many hundreds of ... [his] subjects', reprinted in Free Russia, July 1909 (no volume or part number), p. 11.

${ }^{64}$ The Times, 29 Aug. 1898, p. 3.
} 
among people. ${ }^{65}$ Spence Watson himself, however, went so far as to describe the tsar's call as 'the greatest event of my life'. ${ }^{66}$ Perhaps peace meant so much to him that a chance of promoting it trumped his mistrust of Russia. If so, he should have thought again, for the conference at The Hague drew up some non-binding conventions but did almost nothing to slow down the arms race. W. T. Stead, furthermore, a north-east Englishman who had risen to become one of Britain's most prominent journalists, ran a nationwide peace campaign between the tsar's call and the opening of the conference which fell short of the hopes of pacifists. ${ }^{67}$ Thus, by the time the tsar's initiative had run its course, Spence Watson's hopes had been dashed. Although they surfaced again at the time of a follow-up conference in 1907 , by then, in the light of the tsarist regime's violence in the course of the 1905 revolution and its aftermath, he no longer thought Russia was the right country to chair such a meeting, and, having discussing the matter with Britain's Prime Minister, he knew too much about the conference to be sanguine about its likely outcome. ${ }^{68}$

By then, too, the international arms race had accelerated, for the first of the Dreadnought class of battleships had been launched in 1906. Spence Watson had just complained, in an essay on 'Britain's Militarism', that 'we keep up the image of Christ on our altars, but the gods we worship are Mammon and Moloch'. ${ }^{69}$ The following year, he was one of the four signatories of a letter from the National Council of Peace Societies which urged MPs to divert 'the money which we are going to throw away over battleships and over their guns and ammunition' to 'good, useful, and most important purposes' ${ }^{70}$ In 1908 , he decried

\footnotetext{
${ }^{65}$ Esper Serebryakov, 'How to check Militarism’, Free Russia 10 (June-July 1899), №№ 6-7, pp. 53-5.

${ }^{66}$ Corder, Life, p. 278.

${ }^{67}$ Stead acknowledged the unpopularity of his campaign in a letter of thanks to the editor of the Manchester Guardian: 'Everywhere among the Friends of Peace, I find the most grateful recognition of the single-handed fight which you have waged against great odds' (Spence Watson/Weiss Papers, SW/1/17/76, Stead to C. P. Scott, 14 Dec. 1898).

${ }^{68}$ Spence Watson/Weiss Papers, SW/1/17/79, Stead to Spence Watson, 22 Nov. 1907; SW/1/3/6, CampbellBannerman to Spence Watson, 20 Apr. 1907; SW/3/22, Spence Watson to his wife, 27 Jul. 1907.

${ }^{69}$ Robert Spence Watson, 'Britain’s Militarism', Advocate of Peace, vol. 68, № 2 (February 1906), p. 39 (dated December 1905 at the end).

${ }^{70}$ The Times, 9 Nov. 1907, p. 4.
} 
the need for more dreadnoughts; from the point of view of Liberals, he wrote, 'all this is absolutely contrary to what we have always professed. In this we are doing the work of the Tory Party, and the dirty work of the Tory Party'. ${ }^{71}$

Thus Spence Watson's commitment to the cause of peace barely changed in the course of his many decades of reflection and action. In the Crimean War, the Balkan crisis of the mid-1870s, the Anglo-Zulu War, Britain's Sudanese adventures, and the Boer War, he pressed consistently for his country to stay out or get out of military affairs. Despite being involved with Russian revolutionaries for more than twenty years, he never contemplated using force to undermine the tsarist regime. He was so enthusiastic about disarmament that, in 1898 , he briefly allowed his excitement to overcome his profound mistrust of the tsar. He spoke out even against his own Liberal Party when it committed money to building Dreadnoughts. A case can be made for the view that he was the most consistent and most energetic British peace activist of the later nineteenth and early twentieth centuries.

Because, by the end of his life, Spence Watson had become a national as well as a local figure (not least by virtue of having become President of the Peace Society in 1903, a position he retained until his death in 1911), it may seem that he was no longer rooted in north-east England. In fact, he remained strongly committed to the north. A separate essay could be written on his work for the maintenance of peaceful relations between employers and employees in industry, which had much less to do with world affairs than with social changes in the vicinity of his home in Gateshead. ${ }^{72}$ Although he was often to be found at the National Liberal Club in London, and although he probably left some of his strictly northeastern pacifist activities to his wife (for she too was energetic in the cause ${ }^{73}$ ), he expressed

\footnotetext{
${ }^{71}$ Robert Spence Watson, 'The Great British Nation Frightened of a Ghost!', Advocate of Peace, vol. 70 , № 4 (April 1908), p. 87.

${ }^{72}$ For an interview he gave on this aspect of his activities (under the title 'Thirty Years' Experience as an Arbitrator'), see Anon, Conciliation in Trade Disputes (Newcastle upon Tyne, 1894), pp. 16-18.

${ }^{73}$ See Ann Craven, 'The Genteel Militant: Elizabeth Spence Watson's Work for Women's Suffrage and Peace', North East History 47 (2016), 73-85.
} 
pride, at the end of his life, in the fact that the Newcastle meeting which deplored the Royal Titles Bill of 1876 was addressed by no-one from more than two miles away, and regretted the fact that, in the early twentieth century, it was difficult to attract large audiences in northeast England without inviting major speakers from the south. ${ }^{74}$ Memory of his pacifism lived on in Newcastle, for a local newspaper said of one of the clashes over peace which took place in the city after the Russian Revolution of February 1917 that 'Not since the memorable peace meeting during the Boer War [at which Spence Watson risked his life] have such stormy scenes been witnessed at a Newcastle meeting as those which took place in Central Hall on Saturday. ${ }^{75}$

Thus the pacifism which was voiced in Newcastle by the local auxiliary of the Peace Society between the Congress of Vienna and the coming of Bismarck continued to be voiced there between the Franco-Prussian and the First World Wars. At one time or another in the nineteenth and early twentieth centuries, all the town's main venues for public debate - the Lecture Room in Nelson Street, the Town Hall, Salem Chapel in Hood Street, the Friends Meeting House in Pilgrim Street, Wilcke's Temperance Hotel in Westgate Street, the Bigg Market, the Central Hall in Elswick - resounded with arguments between peace advocates and their opponents. If it were not contrary to the spirit of a paper on pacifism, one might claim that Newcastle experienced a century-long 'war about war'. Although it may be the case that the raw materials, manufactured goods, and commerce of north-east England conspired in favour of forward policies in respect of international affairs, the local case for peace did not go unheard.

The nature of Newcastle pacifism, however, was probably more important than its longevity. For two main reasons, it warrants attention in general accounts of peace advocacy.

\footnotetext{
${ }^{74}$ Spence Watson, Reminiscences, pp. 64, 78.

${ }^{75}$ NDJ, 30 Jul. 1917, p. 3.
} 
First, pacifists in Newcastle were radical even by pacifist standards. Few of them were prepared to contemplate violence of any kind, not even (for example) the possible acceptability of 'defensive' war. This feature of their outlook may have had something to do with the overwhelmingly nonconformist (and especially Quaker) aspect of their composition, or with the extreme severity of the invective to which their opponents subjected them (which perhaps inclined the half-hearted among them either to abandon the cause or to adhere to their views with greater resolution). Second, Newcastle pacifism produced in Robert Spence Watson a personality who appealed to a wider constituency than their own. Some peace activists seemed eccentric; Spence Watson was congenial. Some were strident; Spence Watson kept himself in check. Some over-complicated the ideas on which they based their views; Spence Watson explained his position by drawing on the simple Biblical justifications in which he had been brought up. Some looked unpatriotic; Spence Watson's emphases on the disgrace and waste of war challenged the meaning of patriotism. Perhaps above all - and despite the depth of his roots in north-east England - Spence Watson combined prominence in north-east England with prominence in the national Liberal Party, and so greatly boosted the respectability of the radical version of pacifism to which he adhered. 